\title{
Applying Theoretical Models on Human Creativity to Animal Studies
}

\author{
Allison B. Kaufman ${ }^{1 *}$ and James C. Kaufman ${ }^{1}$ \\ ${ }^{1}$ University of Connecticut \\ *Corresponding author (Email: allison.kaufman@uconn.edu)
}

Citation - Kaufman, A. B., \& Kaufman, J. C. (2014). Applying theoretical models on human creativity to animal studies. Animal Behavior and Cognition, 1(1), 78-90. doi: 10.12966/abc.02.06.2014

\begin{abstract}
While creativity in humans has been actively studied for some time, it is only recently been a topic of interest in non-human animals. In order to take advantage of what is already known and to avoid redundancy, communication between those who study humans and animals is crucial. There are several models which are actively used in the study of creativity in humans which can be easily applied to animals to assist with the definition, classification, and characterization of behaviors.
\end{abstract}

Keywords - Creativity, Innovation, Animals, 4 Ps, 4Cs, Geneplore, 5 As, Aesthetic/Functional creativity

"To be creative is to be human. It's really that simple." -- Liz, Kalloch (Radmacher \& Kalloch, 2013, p. 80)

The study of creativity in humans has been an active, ongoing field of research for the last 75 years, with substantial work being done across many disciplines, including psychology, education, business, and neuroscience (Kaufman, 2009). One issue that often arises in the study of human creativity is domain-specific jargon and a general lack of communication; scholars who study "creativity" may not even be aware of studies that use the related concepts of "innovation" or "imagination" (Reiter-Palmon, Beghetto, \& Kaufman, in press). Such disconnect can lead to the wheel being repeatedly reinvented, relabeled, and restudied. Although there are conceptual distinctions between creativity and innovation (and other related words), we will typically use them interchangeably in this paper, preferring to use the terms that the original researchers used.

In a similar fashion, studies of what could be reasonably called "animal creativity" are often instead classified as investigations of problem-solving, tool use, or social learning. These are perfectly reasonable labels to use; however, in this paper, we will bring together many different studies that could be considered to look at animal creativity. Building off of our past work that has tried to link human and animal creativity (Kaufman, Butt, Kaufman, \& ColbertWhite, 2011; Kaufman \& Kaufman, 2004), we will then discuss theories that are frequently used in the study of human creativity and highlight how these different models might offer different possible taxonomies. 
The first thing to do is to consider is the definition of creativity. Most creativity researchers consistently focus on two central requirements: novelty and task appropriateness (Barron, 1955; Guilford, 1950; Kaufman, 2009; Sawyer, 1999). Simonton (2012) even argues it is a zero sum equation - with no novelty, something can be incredibly task appropriate yet not creative (and vice versa). This particular black and white type definition is appealing when considering evolutionary advantages of innovation, as inappropriate behavior often has dire consequences for survival.

Moving beyond a basic definition, the central conceptual theory in human creativity is that of the four Ps (Rhodes, 1962). The Four Ps stand for: the creative Person (the one who creates), the creative Process (how one creates), the creative Product (the result of the creation a new concept or work), and the creative Press (the ways that the surrounding environment may nurture or impede creativity).

More recently, Glăveanu (2013) argued for an adapted version of the four Ps called the five As. Placing a higher emphasis on the context of creativity, he shifted the terms to reflect an interaction within the environment. The Person becomes the Actor; the Process becomes the Action; the Product becomes the Artifact. The Press is split into two different concepts. The Audience encompasses both those people who might initially respond to a creative work as well as the eventual (possible) larger audience. The Affordances represent the actual physical things needed to create.

The four Ps (or the five As) can offer an excellent framework for animal creativity as well. They can also encompass many other theories rooted in human research that can be at least partially applied to animal behavior.

\section{Person}

Studies of the creative person attempt to describe and predict who is more likely to be creative. They might, for example, look at individual differences in such related constructs as personality, motivation, and cognition. One theory related to the creative person, the Four Cs, is rooted in levels of creative eminence and development. It can help to further parse studies of the creative person or animal; and we will now switch to discussing animal research and how these human-based theories and ideas may be applied.

\section{The Four C Model in Animals}

Many discussions of creativity tend to focus on one of two levels of creativity: everyday (or "little-c") creativity and genius-level (or "Big-C") creativity. Kaufman and Beghetto (2009) proposed two additional categories in their Four C Model of Creativity: "mini-c" and "Pro-c." Mini-c creativity consists of subjective self-discoveries - the new and personally meaningful insights and interpretations that are a component in the learning process. Pro-c creativity is expert-level creativity which has yet to reach genius status. A person may initially be mini-c and then grow with feedback to become little-c (in which others recognize his or her creativity). With practice (often ten years), that person may become Pro-c; a select few, with the passage of time, may be considered by society to be so eminent as to warrant the Big-C designation. 
Mini-c. In an animal population, mini-c is characterized by situation-specific innovations that an animal uses to obtain a goal. These innovations are unique to a certain set of circumstances and the mini-c innovator is the sole individual responsible for the innovation. For example, the first dolphin to use a sponge for foraging (Krutzen et al., 2005) and the first bird to open a milk bottle cap (Lefebvre, 1995) were innovators in novel situations (food buried in rocky substrate and available milk bottles, respectively), and they were solely responsible for the novel solutions applicable.

What makes an animal more or less inclined to be creative? In some ways, the answer is similar to what makes a person apt to create. For people, the personality trait of openness to experience is most related to creativity; this factor encompasses intellectual and experiential curiosity and novelty-seeking (Kyllonen, Walters, \& Kaufman, 2005). The connection between openness to experience and creativity is found whether measured through reported creative accomplishments (Griffin \& McDermott, 1998), rated creativity (Wolfradt \& Pretz, 2001), or divergent thinking tests (King, Walker, \& Broyles, 1996; McCrae, 1987).

In animals, the concept of personality is also salient. Many researchers define animal personality as how behavior does or does not vary across individuals within species (Dingemanse, Réale, \& Reale, 2005; Reale et al., 2007), and there is strong evidence for individual differences in behavior both in the wild and in captivity. Such behavioral differences have been found in a variety of species, including primates (Herrmann et al., 2010) and dolphins (Highfill \& Kuczaj, 2010).

More than four decades ago, Chamove, Eysenck, and Harlow (1972) designed experiments to elucidate animal personality. They found three distinct personality factors in rhesus monkeys - fear, hostility, and affection - to be evident in social situations. Studies have also specifically related personality to innovation. For example, dolphins who use sponges to forage spend more time alone and invest more time in foraging that traditional foragers (Mann et al., 2008). These behavioral characteristics may map on to the human-based concepts of introversion and conscientiousness. In Nambian Rock Agamas (Agama planiceps), initial studies of boldness and risk taking (characteristics used to approximate creative capabilities in animals with lower cognitive capacities, (see Dellu et al., 1993; Kaufman et al., 2011) not only found individual variation in the amount of time the lizard spent out in the open (Carter, Goldizen, \& Tromp, 2010), but also showed that this variation is seasonally dependent and reflects an interaction between individual and season. Both boldness and behavioral plasticity can thus be considered personality traits, in that they are stable in each individual but vary between individuals (Carter, Goldizen, \& Heinsohn, 2012; Carter et al., 2010), much as they do in humans (Goldberg, 1992). Finally, tests of problem solving in great tits (Parus major) showed that the ability to solve multiple types of problems was consistent in individuals over time and task type. This ability was independent of novelty exploration (i.e., boldness), again providing support for the idea these types of skills may be linked to stable personality traits (Cole, Cram, \& Quinn, 2011).

Of the three specific studies detailed in the previous paragraph, we chose to highlight two which deal with species less frequently used in studies of cognition, and therefore show the breadth of the research. It is important to note, however, there are also plentiful examples of boldness, risk taking, and innovation as personality traits in many other species. These include primates (Chamove et al., 1972; Freeman et al., 2013), rats (Dellu et al., 1993), and dolphins (Highfill \& Kuczaj, 2007, 2010). Gosling (2001) also provides an excellent review of the measurements used and traits identified in these personality studies. Lastly, there is also the 
possibility that a genetic component to risk taking exists, as two difference species of tits (Parus spp.) have shown a links between exploration and the DRD4 gene (Fidler et al., 2007; Kluen, Kuhn, Kempenaers, \& Brommer, 2012).

Little-c. The moment a second animal joins the first animal in performing a novel behavior, the original creator rises to the level of little-c. At this point, the creativity has been acknowledged by someone else - it has been used at a population level. Although it may continue to have personal meaning for the original creator, it is no longer exclusively personal. Tool use within a population is an excellent example - for example, leaf rolling (Byrne \& Byrne, 1993) or termite fishing (McGrew \& Marchant, 1999) are established methods of foraging among primates at the population level. These behaviors are now well-known within the animal world, but they did not spontaneously emerge. In the very beginning, one chimp had a mini-c insight and was the first to use a stick to fish termites out of their nest. As the population acknowledged the utility of the behavior, it became little-c. These techniques are used by large numbers of animals and are often learnt by younger individuals via observation of the group as a whole (Povinelli, Eddy, Hobson, \& Tomasello, 1996; Tomasello, Davis-DaSilva, Camak, \& Bard, 1997).

There is a social component here as well; animals in a group seem to be aware of the best innovators. Similarly, within humans, people with a certain degree of expertise tend to recognize and agree on what products are (or are not) creative (Amabile, 1996; Kaufman \& Baer, 2012; Kaufman, Baer, \& Cole, 2009; Kaufman et al., 2013). Humans might eagerly await a new movie from Pixar Studios but be less enthusiastic about whatever Dreamworks does next; so, too, can animals hone in on their most creative peers when learning new tasks such as tool use (Ottoni, de Resende, Izar, \& Resende, 2005).

Pro-c. Some individual animals may reach Pro-c, and become expert innovators. In this area, one of the best known examples is Imo, the Japanese Macaque (Macaca fuscata) responsible for both sweet potato and wheat washing among her troop (Kawai, 1965). When she was 18 months old, Imo learned to dip sweet potatoes in water to wash off dirt instead of doing so manually. This behavior soon spread to the rest of the group. At a later point, when given piles of rice or wheat mixed with sand, Imo learned to throw the mixture into water to separate the substances (the sand sunk, the wheat/rice floated). Again, her troop mates followed suit. Imo showed Pro-c innovation by creating multiple behaviors which became well-known in her society. As much as an ape can be said to truly be an expert-level creator, Imo qualifies.

Another candidate for Pro-c is Betty the crow (Corvus moneduloides), who to date has shown the ability to innovate tools in multiple ways and in multiple scenarios (Weir, Chappell, \& Kacelnik, 2002; Weir \& Kacelnik, 2006; Wimpenny, Weir, \& Kacelnik, 2011). She lacks a peer community that might recognize her as such, although her human caretakers believe she stands out. 
Big-C. The distinction between Pro-c and Big-C is traditionally rooted in the passage of time and historical acclaim. Animals themselves, to our knowledge, do not have a sense of history from before their birth. In fiction, a spider like Charlotte will live on in Wilbur's heart, and he will communicate her heroism to her children and her children's children. Charlotte's legacy might therefore qualify as Big-C (White, 1952). Unfortunately, Charlotte and Wilbur are fictional and thus cannot be included in our model. A human uneducated in music will likely still be able to recognize the names of Mozart or Beethoven. Even the animals who might seem contenders for Big-C - Imo the macaque (Kawai, 1965), Betty the crow (Weir et al., 2002), Kanzi the bonobo (Pan paniscus; Savage-Rumbaugh \& Lewin, 1994), or Alex the African Grey (Psittacus erithacus; Pepperberg, 1999) - will only elicit a blank stare from even the most educated conspecific.

If Big-C translates poorly to the animal kingdom, the range of mini-c to Big-C can still hold true. One way to think of it is that every creature has the capacity to be creative. A young boy writing his first poem has the same potential to create as does Maya Angelou. Every crow has the necessary physiology to create as does Betty the Crow. But that does not mean that the young boy or the crow will have that splendid mix of personality, intellect, drive, sensibility, and imagination that leads to such meaningful work.

\section{Press (Affordances and Audience)}

In animal innovation, two types of resources are available to the individual - physical and social. Physical resources (what Glăveanu, 2013, would call Affordances) are just that materials used for construction of a creative product. The specific availability of basic materials are sometimes overlooked in theories of human creativity in favor of larger questions of emotional support - how parents might nurture creativity in their children (Miller, Lambert, \& Neumeister, 2012) or how a boss or peers can instill a feeling of psychological safety in which it is okay to be creative (Ford \& Sullivan, 2004). When physical considerations are brought into play, it is usually in analyzing socioeconomic status and creativity (Ivcevic \& Kaufman, 2013).

In the animal world, however, obtaining building materials is often risky business. It can entail stealing or actively searching them out and, thus, exposure to danger (Doerr, 2012; Morand-Ferron, Sol, \& Lefebvre, 2007). This linkage is then connected in turn to selection; animals more skilled in obtaining materials for endeavors important to survival and reproduction are the ones who produce more offspring (Doerr, 2010). A key example is the Australian bowerbird (Ptilonorhynchus violaceus). In this species, males build elaborate bowers (nests) and "dance" in front of them to court females. Shiny objects embedded in the bowers and elaborate dances are more likely to show fitness and be attractive to females (Borgia, 1985). Obtaining the materials for construction of the bower (the creative press or the affordances) is crucial to the creativity and originality of the bower, and consequently the reproductive fitness of the bird. Likewise a tool using animal would be unable to create tools without access to starter materials which could subsequently be shaped.

In addition, Press includes a social aspect (what Glăveanu, 2013, would call Audience). Many animals live socially and are affected by others in their group. Studies of neophobia and exploration have had conflicting results, but all agree that there is change in how an individual's reacts to novel items or experiences depending on the social situation. Most studies suggest that, at least in birds, neophobia increases with the addition of individuals to a group (Griffin, Lermite, Perea, \& Guez, 2013; Overington, Cauchard, Morand-Ferron, \& Lefebvre, 2009; Stöwe 
et al., 2006; van Oers, 2005). In some cases, however, particularly when flocks of birds were studied, exploration of novelty and problem solving increased with group size. The authors of these studies hypothesize that this might be due to a diversity of skills, problem solving, and competence (Liker \& Bókony, 2009; Morand-Ferron \& Quinn, 2011).

In humans, team creativity is often associated with the composition of the team. Diverse perspectives, for example, tend to increase group creativity if the people on the team can both elaborate their own positions (van Knippenberg, De Dreu, \& Homan, 2004) and understand the viewpoints of their fellow members (Hoever, van Knippenberg, van Ginkel, \& Barkema, 2012). The ability to understand that others have knowledge that can be of use may also be present in animals. Evidence of metacognition has been repeatedly found in primates (Beran, Smith, \& Perdue, 2013; Hare, Call, \& Tomasello, 2001; Schel et al., 2013; Smith \& Washburn, 2005), and even pigeons may be aware of their own knowledge limits and when hints may be helpful in problem solving (Iwasaki, Watanabe, \& Fujita, 2013). Metacognition is broadly associated with creativity and increased problem solving in humans (Davidson \& Sternberg, 1998; Feldhusen \& Goh, 1995; Kaufman \& Beghetto, 2013). There is evidence of this connection in animals, as well (Greenberg, Hamann, Warneken, \& Tomasello, 2010; Lopuch \& Popik, 2011; Plotnik, Lair, Suphachoksahakun, \& de Waal, 2011; Yamamoto \& Tanaka, 2009).

Perhaps the group only influences part of behavior. In New Caledonian crows (Corvus moneduloides), hand raised crows (without contact with any other crows) will perform a stereotyped pattern of interaction with an object that resembles the final use of the object as a tool, suggesting there is some sort of fixed action pattern which helps develop the ability to use tools (reminiscent of the distorted songs of birds raised in isolation; see Ball \& Hulse, 1998). The influencing group does not have to consist of conspecifics; crows that witnessed humans using tools learned to use the same tools faster (although naïve crows eventually learned as well). These crows preferred to work with objects which they had seen humans use as tools (Kenward, Rutz, Weir, \& Kacelnik, 2006). Kummer and Goodall (1985) provide an excellent review of potential social and environmental connections conductive to innovative behavior - all in and of themselves worthy of separate study - including subordinate status, excess time or energy (such as times of plentiful resources in the wild or animals in captivity), and competition (reproductive, social, or otherwise).

\section{Product}

In animals, the creative product is fairly straightforward; it is the innovative tool, skill, or adaptation acquired. Functionality is likely the most practical judge of success in this category, and Cropley and Cropley's $(2008,2010)$ human-based distinction between functional and aesthetic creativity is helpful to consider here. Most attempts to measure creative products tend to focus on artistic work, such as poems, paintings, or music (Kaufman, Plucker, \& Baer, 2008). As mentioned earlier, creativity is traditionally defined as something both original and task appropriate; for aesthetic products, the emphasis tends to be on originality. Most aesthetic works have wide license for what would be considered "task appropriate." Indeed, it is hard to imagine how many free verse poems might be considered not task appropriate. Cropley and Cropley argue that creative work that has a useful social purpose needs a stronger emphasis on task appropriate. For example, a bridge may be very original and be beautiful to look at - but if it collapses, it is not a "task appropriate" bridge. Cropley and Cropley thus propose a distinction 
between functional creativity, which requires effectiveness, and aesthetic creativity, which does not.

\section{Aesthetic and functional creativity in animals}

In the animal world, innovative products which are not task appropriate do not last long. Most creative products would fall under functional creativity. There are, however, a few examples of aesthetic creativity in animals. The best of these are the previously mentioned bowers built by male Australian bowerbirds to attract mates (Borgia, 1985). Working on the assumption that bowers are all functional (i.e., the birds are well versed enough in bower making that bower collapse is not an issue), a bowerbird's creative success (as measured by his ability to attract a mate) depends solely on how aesthetically pleasing his mate judges his bower to be.

Some studies examined whether animals (specifically pigeons) can discern works of art (Watanabe, Sakamoto, \& Wakita, 1995; Watanabe, 2010). While these studies are largely based on conditioning (i.e., subjects were taught using reinforcement to discriminate between Picasso and Monet, or between "good art" and "bad art"), it is still notable that pigeons are able to discriminate between the two artists' paintings in the first place. Likewise, there is evidence within the human creativity field that people can be taught to develop aesthetic judgment to mirror that of experts. Novices generally do not agree with experts on the creativity of products, although this varies by domains (Kaufman \& Baer, 2012; Kaufman, Baer, Cole, \& Sexton, 2008; Kaufman et al., 2009, 2013). However, Dollinger and Shafran (2005) were able to train novice judges on aesthetic judgment by showing them drawings from a different study along with expert ratings for these drawings. These novices, thus trained, showed stronger agreement with experts. Along these lines, there are also product rating scales that ask many specific questions about a product's creativity (as opposed to a global score). Novices tend to better approach expert judgments in these cases (Besemer \& O’Quin, 1999; Cropley \& Kaufman, 2012).

\section{Process}

Of the four Ps, the process is the hardest to fit into an animal model. Most human-based work on creative problem solving (see Sawyer, 2012) is possible because humans can verbalize their thoughts during the actual act of being creative (Pretz, 2008) or retrospectively in interviews (Csikszentmihalyi, 1996). Animals are unable to participate in think-aloud protocols.

The closest approximation is work which differentiates planning and insight. For example, apes have been shown to possess the ability to understand physical cause-and-effect, classification by function, and multiple uses for an item. They can also combine smaller behavioral competencies into larger behavioral components and programs (Russon et al., 2008).

\section{The Geneplore model in animals}

The Geneplore model of creativity from human-based work may be applied to animal studies. This model is an expansion of one of creativity's core ideas: divergent and convergent thinking. Guilford (1950), as part of his Structure of Intellect theory of intelligence, conceived of divergent thinking as coming up with many different ideas (often in response to a question with no one clear answer) and convergent thinking as being able to select the best solution out of a variety of possibilities. 
Finke, Ward, and Smith (1992) built their Geneplore model from these core concepts. In this model, there are two phases: generative and explorative. In the generative phase, someone constructs a preinventive structure, or a mental representation of a possible creative solution. These are the ideas that are bandied about in brainstorming as one tries to solve a problem. Many different preinventive structures may be created in this phase. In the explorative phase, one considers the different preinventive structures in relation to the constraints of the final goal. There may be several cycles between the generative and explorative phase before a creative work is produced.

Experimental data on whether animals plan tasks (i.e., generate ideas) has been mixed. Lab studies in which monkeys were trained on tasks and monitored have yielded results showing situations in which planning both occurred and did not occur (Beran \& Parrish, 2012; Scarf \& Colombo, 2009; Scarf et al., 2010). Many of these studies, however, use a specific paradigm to measure planning in which a scenario is presented to the animal and subsequently changed. Planning is then measured by the subsequent number of errors (Terrace, 1984). This metric assumes that the subject automatically executes the plan as originally developed (therefore making errors) and does not change the plan as the task progresses (which might happen if the animal were to realize the task had changed). Animals that engaged in more natural problem solving tasks which require planning appeared to fare better (Kuczaj, Xitco, \& Gory, 2010; Osvath, 2009; Wimpenny et al., 2011).

The problem, of course, lies with the fact that with the exception of instances of trial and error, we cannot know the actual cognitive process an animal uses to select the best solution to a problem (if, indeed, the animal is able to consciously select from a group of potential solutions). Even trial and error is largely a sequential process, as opposed to a simultaneous comparison of options. Figaro, a cockatoo (Cacatua goffiniana) who broke off a splinter of wood to retrieve a cashew placed out of reach (Auersperg, Szabo, von Bayern, \& Kacelnik, 2012), may have considered all available materials surrounding him - or he may have seen the piece of wood and had a moment of insight. Upon discovering the piece of wood was too long, Figaro modified the tool. Again, this action is an example of the best solution to the problem (being that the original tool did not work), but we cannot know how Figaro arrived at the solution.

\section{Conclusion and Applications}

Those scholars studying creativity across different disciplines need to communicate to avoid accidentally repeating studies and rehashing old concepts. Communication between researchers studying creativity in humans and animals is also vital, albeit for different reasons. Speaking the same language and working within comparable paradigms allows us to build off one another's work. The assumption in the epigram - that creativity is reserved for humans - is commonly accepted by laypeople. Yet as we have reviewed, there is extensive evidence that animals are creative and their abilities and contributions can be placed in human-based models such as the 4 Ps (or 5 As), 4 Cs, function/aesthetic creativity, and the Geneplore model.

Why does this matter? Human research and models can suggest capabilities yet to be tested (or developed) in the animal world. Animal studies can expand on the very nature of what is considered creativity. For example, Simonton (1990) has argued that the four Ps should be expanded to include Persuasion. The importance of social learning to animal creativity suggests that if the four Ps are intended to cover a broad conception of creativity, then Simonton's point is particularly well taken. 
Animal research has reclaimed many core abilities which were once considered the exclusive purview of humans - for example, mirror self recognition (Anderson \& Gallup, 2011; Gallup, 1970), theory of mind (Call \& Tomasello, 2008), and social learning (Ottoni et al., 2005; Petrosini et al., 2003). The pioneering efforts of many of those researchers discussed in this paper have suggested that animals are creative, too. It would be a worthy goal to build off of the human-based theories to pinpoint the extent of the possibilities.

\section{References}

Amabile, T. M. (1996). Creativity in context: Update to "the social psychology of creativity." Boulder, CO: Westview Press.

Anderson, J. R., \& Gallup, G. G. (2011). Which primates recognize themselves in mirrors? PLoS Biology, 9, 1-3.

Auersperg, A. M. I., Szabo, B., von Bayern, A. M. P., \& Kacelnik, A. (2012). Spontaneous innovation in tool manufacture and use in a Goffin's cockatoo. Current Biology, 22, R903-904. doi:10.1016/j.cub.2012.09.002

Ball, G. E., \& Hulse, S. H. (1998). Birdsong. American Psychologist, 55, 37-58.

Barron, F. (1955). The disposition toward originality. Journal of Abnormal \& Social Psychology, 51, 478-485.

Beran, M. J., \& Parrish, A. E. (2012). Sequential responding and planning in capuchin monkeys (Cebus apella). Animal Cognition, 15, 1085-1094.

Beran, M. J., Smith, J. D., \& Perdue, B. M. (2013). Language-trained chimpanzees (Pan troglodytes) name what they have seen but look first at what they have not seen. Psychological Science, 24, 660-666. doi:10.1177/0956797612458936

Besemer, S. P., \& O'Quin, K. (1999). Confirming the three-factor creative product analysis matrix model in an American sample. Creativity Research Journal, 12, 287-296.

Borgia, G. (1985). Bower quality, number of decorations, and mating success of male satin bowerbirds (Ptilonorhynchus violaceus): An experimental analysis. Animal Behavior, 33, 266-271.

Byrne, R. W., \& Byrne, J. M. E. (1993). Complex leaf-gathering skills of mountain gorillas (Gorilla g. beringei): Variability and standardization. American Journal of Primatology, 31, 241-261.

Carter, A. J., Goldizen, A., \& Heinsohn, R. (2012). Personality and plasticity: Temporal behavioural reaction norms in a lizard, the Namibian rock agama. Animal Behaviour, 84, 471-477.

Carter, A. J., Goldizen, A. W., \& Tromp, S. A. (2010). Agamas exhibit behavioral syndromes: Bolder males bask and feed more but may suffer higher predation. Behavioral Ecology, 21, 655-661. doi:10.1093/beheco/arq036

Chamove, A. S., Eysenck, H. J., \& Harlow, H. F. (1972). Personality in monkeys: Factor analyses of Rhesus social behavior. Quarterly Journal of Experimental Psychology, 24, 496-504.

Cole, E. F., Cram, D. L., \& Quinn, J. L. (2011). Individual variation in spontaneous problem-solving performance among wild great tits. Animal Behaviour, 81, 491-498.

Cropley, D. H., \& Cropley, A. J. (2008). Elements of a universal aesthetic of creativity. Psychology of Aesthetics, Creativity, and the Arts, 2, 155-161.

Cropley, D. H., \& Cropley, A. J. (2010). Functional creativity: Products and the generation of effective novelty. In J. C. Kaufman \& R. J. Sternberg (Eds.), Cambridge handbook of creativity (pp. 301-320). New York: Cambridge University Press.

Cropley, D. H., \& Kaufman, J. C. (2012). Measuring functional creativity: Empirical validation of the Creative Solution Diagnosis Scale (CSDS). Journal of Creative Behavior, 46, 119-137.

Csikszentmihalyi, M. (1996). Creativity. New York: Harper Collins.

Davidson, J. E., \& Sternberg, R. J. (1998). Smart problem solving: How metacognition helps. In D. J. Hacker, A. C. Graesser, \& J. Dunlosky (Eds.), Metacognition in educational theory and practice (pp. 47-69). Mahwah, New Jersey: Lawrence Erlbaum.

Dellu, F., Mayo, W., Piazza, P. V. V, Le Moal, M., \& Simon, H. (1993). Individual differences in behavioral responses to novelty in rats. Possible relationship with the sensation-seeking trait in man. Personality and Individual Differences, 15, 411-418. doi:10.1016/0191-8869(93)90069-F

Dingemanse, N. J., Réale, D., \& Reale, D. (2005). Natural selection and animal personality. Behaviour, 142, 11591184. doi:10.1163/156853905774539445

Doerr, N. R. (2010). Does decoration theft lead to an honest relationship between male quality and signal size in great bowerbirds? Animal Behaviour, 79, 747-755. 
Doerr, N. R. (2012). Male great bowerbirds accumulate decorations to reduce the annual costs of signal production. Animal Behaviour, 83, 1477-1482. doi:10.1016/j.anbehav.2012.03.021

Dollinger, S. J., \& Shafran, M. (2005). Note on consensual assessment technique in creativity research. Perceptual and Motor Skills, 100(3 Pt 1), 592-598.

Feldhusen, J. F., \& Goh, B. E. (1995). Assessing and accessing creativity: An integrative review of theory, research, and development. Creativity Research Journal, 8, 231-248.

Fidler, A. E., van Oers, K., Drent, P. J., Kuhn, S., Mueller, J. C., \& Kempenaers, B. (2007). Drd4 gene polymorphisms are associated with personality variation in a passerine bird. Proceedings. Biological sciences / The Royal Society, 274, 1685-1691. doi:10.1098/rspb.2007.0337

Finke, R. A., Ward, T. B., \& Smith, S. M. (1992). Creative cognition: Theory, research, and applications. Cambridge, MA: MIT Press.

Ford, C., \& Sullivan, D. M. (2004). A time for everything: How timing of novel contributions influences project team outcomes. Journal of Organizational Behavior, 21, 163-183.

Freeman, H. D., Brosnan, S. F., Hopper, L. M., Lambeth, S. P., Schapiro, S. J., \& Gosling, S. D. (2013). Developing a comprehensive and comparative questionnaire for measuring personality in chimpanzees using a simultaneous top-down/bottom-up design. American Journal of Primatology, 75, 1042-1053. doi:10.1002/ajp.22168

Gallup, G. G. (1970). Chimpanzees: Self recognition. Science, 167, 86-87.

Glăveanu, V. P. (2013). Rewriting the language of creativity: The Five A's framework. Review of General Psychology, 17, 69-81.

Goldberg, L. R. (1992). The development of markers for the Big-Five factor structure. Psycholocial Assessment, 4 , $26-42$.

Gosling, S. D. (2001). From mice to men: What can we learn about personality from animal research? Psychological Bulletin, 127, 45-86.

Greenberg, J. R., Hamann, K., Warneken, F., \& Tomasello, M. (2010). Chimpanzee helping in collaborative and noncollaborative contexts. Animal Behaviour, 80, 873-880.

Griffin, A. S., Lermite, F., Perea, M., \& Guez, D. (2013). To innovate or not: contrasting effects of social groupings on safe and risky foraging in Indian mynahs. Animal Behaviour, 86, 1291-1300.

Griffin, M., \& McDermott, M. R. (1998). Exploring a tripartite relationship between rebelliousness,openness to experience, and creativity. Social Behavior and Personality: An International Journal, 26, 347-356. doi:10.2224/sbp.1998.26.4.347

Guilford, J. P. (1950). Creativity. American Psychologist, 5, 444-454.

Hare, B. A., Call, J., \& Tomasello, M. (2001). Do chimpanzees know what conspecifics know? Animal Behaviour, 61, 139-151.

Herrmann, E., Hernández-Lloreda, M. V., Call, J., Hare, B. A., \& Tomasello, M. (2010). The structure of individual differences in the cognitive abilities of children and chimpanzees. Psychological Science, 21, 102-110. doi:10.1177/0956797609356511

Highfill, L. E., \& Kuczaj, S. A. (2007). Do bottlenose dolphins (Tursiops truncatus) have distinct and stable personalities? Aquatic Mammals, 33, 380-389.

Highfill, L. E., \& Kuczaj, S. (2010). How studies of wild and captive dolphins contribute to our understanding of individual differences and personality. International Journal of Comparative Psychology, 23, 269-277.

Hoever, I. J., van Knippenberg, D., van Ginkel, W. P., \& Barkema, H. G. (2012). Fostering team creativity: Perspective taking as key to unlocking diversity's potential. The Journal of Applied Psychology, 97, 982996. doi:10.1037/a0029159

Ivcevic, Z., \& Kaufman, J. C. (2013). The can and cannot do attitude: How self-estimates of ability vary across ethnic and socioeconomic groups. Learning and Individual Differences, 27, 144-148.

Iwasaki, S., Watanabe, S., \& Fujita, K. (2013). Do pigeons (Columba livia) seek information when they have insufficient knowledge? Animal Cognition, 16, 211-21. doi:10.1007/s10071-012-0566-y

Kaufman, A. B., Butt, A. E., Kaufman, J. C., \& Colbert-White, E. N. (2011). Towards a neurobiology of creativity in nonhuman animals. Journal of Comparative Psychology, 125, 255-272.

Kaufman, J. C. (2009). Creativity 101. New York: Springer.

Kaufman, J. C., \& Baer, J. (2012). Beyond new and appropriate: Who decides what is creative? Creativity Research Journal, 24, 83-91. doi:10.1080/10400419.2012.649237

Kaufman, J. C., Baer, J., \& Cole, J. C. (2009). Expertise, domains, and the consensual assessment technique. The Journal of Creative Behavior, 43, 223-233. doi:10.1002/j.2162-6057.2009.tb01316.x 
Kaufman, J. C., Baer, J., Cole, J. C., \& Sexton, J. D. (2008). A comparison of expert and nonexpert raters using the consensual assessment technique. Creativity Research Journal, 20, 171-178. doi:10.1080/10400410802059929

Kaufman, J. C., Baer, J., Cropley, D. H., Reiter-Palmon, R., \& Sinnett, S. (2013). Furious activity vs. understanding: How much expertise is needed to evaluate creative work? Psychology of Aesthetics, Creativity, and the Arts, 7, 332-340.

Kaufman, J. C., \& Beghetto, R. A. (2009). Beyond big and little: The Four C Model of Creativity. Review of General Psychology, 13, 1-12.

Kaufman, J. C., \& Beghetto, R. A. (2013). In praise of Clark Kent: Creative metacognition and the importance of teaching kids when (not) to be creative. Roeper Review, 35, 155-165.

Kaufman, J. C., \& Kaufman, A. B. (2004). Applying a creativity framework to animal cognition. New Ideas in Psychology, 22, 143-155. doi:10.1016/j.newideapsych.2004.09.006

Kaufman, J. C., Plucker, J. A., \& Baer, J. (2008). Essentials of creativity assessment. New York: Wiley.

Kawai, M. (1965). Newly-acquired pre-cultural behavior of the natural troop of Japanese monkeys on Koshima islet . Primates, 6, 1-30.

Kenward, B., Rutz, C., Weir, A. A. S., \& Kacelnik, A. (2006). Development of tool use in New Caledonian crows: Inherited action patterns and social influences. Animal Behaviour, 72, 1329-1343.

King, L. A., Walker, L. M., \& Broyles, S. J. (1996). Creativity and the Five-Factor Model. Journal of Research in Personality, 30, 189-203.

Kluen, E., Kuhn, S., Kempenaers, B., \& Brommer, J. E. (2012). A simple cage test captures intrinsic differences in aspects of personality across individuals in a passerine bird. Animal Behaviour, 84, 279-287.

Krutzen, M., Mann, J., Heithaus, M. R., Connor, R. C., Bejder, L., Sherwin, W. B., ... Sherman, W. B. (2005). Cultural transmission of tool use in bottlenose dolphins. Proceedings of the National Academy of Sciences, 102, 8939-8943. doi:10.1073/pnas.0500232102

Kuczaj, S. A., II, Xitco, M. J., Jr, \& Gory, J. D. (2010). Can dolphins plan their behavior? International Journal of Comparative Psychology, 23, 664-670.

Kummer, H., \& Goodall, J. (1985). Conditions of innovative behaviour in primates. Philosophical Transactions of the Royal Society of London B: Biological Sciences, 308, 203-214.

Kyllonen, P., Walters, A. M., \& Kaufman, J. C. (2005). Noncognitive constructs and their assessment in graduate education: A review. Educational Assessment, 10, 153-184. doi:10.1207/s15326977ea1003_2

Lefebvre, L. (1995). The opening of milk bottles by birds: Evidence for accelerating learning rates, but against the wave-of-advance model of cultural transmission. Behavioral Processes, 34, 43-54.

Liker, A., \& Bókony, V. (2009). Larger groups are more successful in innovative problem solving in house sparrows. Proceedings of the National Academy of Sciences of the United States of America, 106, 78937898. doi:10.1073/pnas.0900042106

Łopuch, S., \& Popik, P. (2011). Cooperative behavior of laboratory rats (Rattus norvegicus) in an instrumental task. Journal of Comparative Psychology, 125, 250-253.

Mann, J., Sargeant, B. L., Watson-Capps, J. J., Gibson, Q. A., Heithaus, M. R., Connor, R. C., \& Patterson, E. (2008). Why do dolphins carry sponges? PloS One, 3, e3868. doi:10.1371/journal.pone.0003868

McCrae, R. R. (1987). Creativity, divergent thinking, and openness to experience. Journal of Personality and Social Psychology, 52, 1258-1265.

McGrew, W. C., \& Marchant, L. F. (1999). Laterality of hand use pays off in foraging success for wild chimpanzees. Primates, 4, 509-513.

Miller, A. L., Lambert, A. D., \& Neumeister, K. L. S. (2012). Parenting style, perfectionism, and creativity in highability and high-achieving young adults. Journal for the Education of the Gifted, 35, 344-365. doi:10.1177/0162353212459257

Morand-Ferron, J., \& Quinn, J. L. (2011). Larger groups of passerines are more efficient problem solvers in the wild. Proceedings of the National Academy of Sciences of the United States of America, 108, 15898-903. doi:10.1073/pnas.1111560108

Morand-Ferron, J., Sol, D., \& Lefebvre, L. (2007). Food stealing in birds: Brain or brawn? Animal Behaviour, 74, 1725-1734. doi:10.1016/j.anbehav.2007.04.031

Osvath, M. (2009). Spontaneous planning for future stone throwing by a male chimpanzee. Current Biology, 90, R90-R91.

Ottoni, E. B., de Resende, B. D., Izar, P., \& Resende, B. D. (2005). Watching the best nutcrackers: What capuchin monkeys (Cebus apella) know about others' tool-using skills. Animal Cognition, 24, 215-219. doi:10.1007/s10071-004-0245-8 
Overington, S. E., Cauchard, L., Morand-Ferron, J., \& Lefebvre, L. (2009). Innovation in groups: Does the proximity of others facilitate or inhibit performance? Behaviour, 146, 1543-1546. doi:10.1163/156853909X450131

Pepperberg, I. M. (1999). The Alex studies: Cognitive and communicative abilities of grey parrots. Cambridge, MA: Harvard University Press.

Petrosini, L., Grazianoa, A., Mandolesib, L., Neria, P., Molinari, M., \& Leggio, M. G. (2003). Watch how to do it! New advances in learning by observation. Brain Research Reviews, 42, 252-264. doi:10.1016/S01650173(03)00176-0

Plotnik, J. M., Lair, R., Suphachoksahakun, W., \& de Waal, F. B. M. (2011). Elephants know when they need a helping trunk in a cooperative task. Proceedings of the National Academy of Sciences of the United States of America, 108, 5116-21. doi:10.1073/pnas.1101765108

Povinelli, D. J., Eddy, T. J., Hobson, R. P., \& Tomasello, M. (1996). What young chimpanzees know about seeing. Monographs of the Society for Research in Child Development, 61, 1-189.

Pretz, J. E. (2008). Intuition versus analysis: Strategy and experience in complex everyday problem solving. Memory \& Cognition, 36, 554-66.

Radmacher, M. A., \& Kalloch, L. (2013). She: A celebration of greatness in every woman. Berkeley, CA: Viva Editions.

Reale, D., Reader, S. M., Sol, D., McDougall, P. T., Dingemanse, N. J., \& Réale, D. (2007). Integrating animal temperament within ecology and evolution. Biological Reviews, 82, 291-318. doi:10.1111/j.1469185X.2007.00010.x

Reiter-Palmon, R., Beghetto, R. A., \& Kaufman, J. C. (in press). Looking at creativity through a BusinessPsychology-Education (BPE) lens: The challenge and benefits of listening to each other. In E. Shiu (Ed.), Creativity research: An interdisciplinary and multidisciplinary research handbook. New York: Routledge.

Rhodes, M. (1962). An analysis of creativity. Phi Delta Kappan, 42, 305-311.

Russon, A. E., van Schaik, C. P., Kuncoro, P., Ferisa, A., Handayani, D. P., \& van Noordwijk, M. A. (2008). Innovation and intelligence in orangutans. In S. A. Wich, S. S. U. Atmoko, T. M. Setia \& C. P. van Schiak (Eds), Orangutans: Geographic variation in behavioral ecology and conservation (pp. 279-299). New York: Oxford University Press.

Savage-Rumbaugh, E. S., \& Lewin, R. (1994). Kanzi: The ape at the brink of the human mind. New York: Wiley and Sons.

Sawyer, R. K. (1999). The emergence of creativity. Philosophical Psychology, 12, 447-469.

Sawyer, R. K. (2012). Explaining creativity: The science of human innovation. Oxford, UK: Oxford University Press.

Scarf, D., \& Colombo, M. (2009). Eye movements during list execution reveal no planning in monkeys (Macaca fascicularis). Journal of Experimental Psychology: Animal Behavior Processes, 35, 587-592.

Scarf, D., Danly, E., Morgan, G., Colombo, M., \& Terrace, H. S. (2010). Sequential planning in rhesus monkeys (Macaca mulatta). Animal Cognition, 14, 317-324. doi:10.1007/s10071-010-0365-2

Schel, A. M., Machanda, Z., Townsend, S. W., Zuberbühler, K., \& Slocombe, K. E. (2013). Chimpanzee food calls are directed at specific individuals. Animal Behaviour, 86, 955-965.

Simonton, D. K. (1990). History, chemistry, psychology, and genius: An intellectual autobiography of historiometry. In M. A. Runco \& R. S. Albert (Eds.), Theories of creativity (pp. 92-115). Newbury Park, CA: SAGE Publications.

Simonton, D. K. (2012). Taking the U.S. Patent Office criteria seriously: A quantitative three-criterion creativity definition and its implications. Creativity Research Journal, 24, 97-106.

Smith, J. D., \& Washburn, D. A. (2005). Uncertainty monitoring and metacognition by animals. Current Directions in Psychological Science, 14, 19. doi:10.1111/j.0963-7214.2005.00327.x

Stöwe, M., Bugnyar, T., Heinrich, B., Kotrschal, K., \& Stowe, M. (2006). Effects of group size on approach to novel objects in ravens (Corvus corax). Ethology, 112, 1079-1088. doi:10.1111/j.1439-0310.2006.01273.x

Terrace, H. S. (1984). Simultaneous chaining: The problem it poses for traditional chaining theory. In R. J. Herrnstein \& A. Wagner (Eds.), Quantitative analyses of behavior. Cambridge, MA: Ballinger Publishing Co.

Tomasello, M., Davis-DaSilva, M., Camak, L., \& Bard, K. (1997). Observational learning of tool use by young chimpanzees. Human Evolution, 2, 175-183.

Van Knippenberg, D., De Dreu, C. K. W., \& Homan, A. C. (2004). Work group diversity and group performance: An integrative model and research agenda. The Journal of Applied Psychology, 89, 1008-1022. doi:10.1037/0021-9010.89.6.1008 
Van Oers, K. (2005). Context dependence of personalities: Risk-taking behavior in a social and a nonsocial situation. Behavioral Ecology, 16, 716-723. doi:10.1093/beheco/ari045

Watanabe, S. (2010). Pigeons can discriminate "good" and "bad" paintings by children. Animal Cognition, 13, 7585. doi:10.1007/s10071-009-0246-8

Watanabe, S., Sakamoto, J., \& Wakita, M. (1995). Pigeons' discrimination of paintings by Monet and Picasso. Journal of the Experimental Analysis of Behavior, 63, 165-174.

Weir, A. A. S., Chappell, J., \& Kacelnik, A. (2002). Shaping of hooks in New Caledonian crows. Science, 297, 981. doi:10.1126/science. 1073433

Weir, A. A. S., \& Kacelnik, A. (2006). A New Caledonian crow (Corvus moneduloides) creatively re-designs tools by bending or unbending aluminium strips. Animal Cognition, 9, 317-334. doi:10.1007/s10071-006-0052-5

White, E. B. (1952). Charlotte's Web. New York: Harper and Brothers.

Wimpenny, J. H., Weir, A. A. S., \& Kacelnik, A. (2011). New Caledonian crows use tools for non-foraging activities. Animal Cognition, 14, 459-64. doi:10.1007/s10071-010-0366-1

Wolfradt, U., \& Pretz, J. E. (2001). Individual differences in creativity: Personality, story writing, and hobbies. European Journal of Personality, 15, 297-310. doi:10.1002/per.409

Yamamoto, S., \& Tanaka, M. (2009). Do chimpanzees (Pan troglodytes) spontaneously take turns in a reciprocal cooperation task? Journal of Comparative Psychology, 123, 242-249. 